\title{
Recombinant DNA: local or federal regulation?
}

AFTER raging through college campuses and state and local government offices throughout the United States, the debate over the risks and benefits associated with recombinant DNA experiments has now reached a critical juncture in the US Congress. In the next few weeks, committees in both the House of Representatives and the Senate are expected to approve their own versions of legislation to regulate recombinant DNA experiments. Although substantial differences of opinion between the House and Senate committees are emerging on key aspects of the legislation, one point in particular has become the focus of a major lobbying effort by members of the scientific community: the extent to which federal regulations governing recombinant DNA activities should over-ride controls adopted by state and local governments.

Some important points of principle are at stake here, and it is no surprise that the matter has become the centre of a controversy. The dilemma facing Congress is this. On the one hand, it would make no sense to have a patchwork of state and local controls on recombinant DNA research so that experiments were regulated more tightly in one city than in another. Genetically modified micro-organisms, after all, would not respect political boundaries, and a uniform set of national (or, preferably, international) controls would therefore make scientific sense. But on the other hand, the debates which have resulted in state and local governments adopting their own regulations have witnessed considerable public participation in scientific decisionmaking and the forging of new links between universities and their surrounding communities-ideals of ten given lip service but seldom put into practice. If the federal government takes away the right of local governments to set their own recombinant DNA regulations, it would risk stifling such developments. Moreover, there is some concern about the political implications of usurping a community's right to decide whether potentially hazardous activities should be permitted in its midst.

Needless to say, the scientific community has come down heavily on the side of federal pre-emption. Indeed, some scientists have publicly stated that they would support federal legislation only if it establishes uniform national regulations. The most prominent statement of such a position came late in April, when the National Academy of Sciences approved a resolution urging Congress to write a provision into the recombinant DNA bill specifically stating that federal controls would over-ride all local regulations. The Academy's resolution, it is worth noting, was endorsed by Robert L. Sinsheimer, of Caltech, a leading critic of current guidelines governing recombinant DNA experiments.

But there has also been weighty testimony from a few scientists and from state and local officials, who have argued that the intervention of local governments in the recombinant DNA debate so far has been beneficial and there is no reason to expect that arbitrary or excessively strict local control will be adopted in the future. Every state and local government which has acted so far has endorsed the NIH guidelines, added a few minor additional precautions, and adopted procedures to enforce them. Even in Cambridge, where town-gown relationships had been notoriously bad, the city council approved recommendations, put forward by a citizens' committee, allowing recombinant DNA experiments to go ahead at Harvard and MIT essentially under the NIH guidelines. The report of the citizens' committee, in fact, provides an excellent example of how a group of lay people can participate effectively in scientific decision-making.

Is it therefore possible to establish uniform national controls without shutting off legitimate and healthy local inquiries? Possibly. Although some key legislators are hanging firmly to the notion that states should be given free licence to do as they please, a consensus seems to be developing in support of a scheme which would allow local changes to national regulations only under special circumstances. Perhaps more important, the scheme would provide local communities with an opportunity to have some input into national regulations.

It would work like this. The Secretary of Health, Education and Welfare (or whoever administers the national regulations) would have to approve local changes to the national rules. Approval would be given only if the local regulations are more strict than the national rules and if the local government can demonstrate that there are special local circumstances or that they are necessary to protect public health. Opportunity would be given for public hearings on the proposed changes. In practice, if a local government can make a good case, it would be likely to trigger changes in the national rules.

Although the arrangements would limit the powers of local government in the recombinant DNA debate, it would give them more authority than they have in areas such as radiation standards and the regulation of food additives. In short it represents a reasonable compromise between total federal pre-emption and the possibility of widely varying local controls. 